\title{
sciendo
}

\section{$\mu$-Crystallin: A thyroid hormone binding protein}

\author{
Christian J. Kinney \& Robert J. Bloch \\ Department of Physiology School of Medicine, University of Maryland, Baltimore, Baltimore, MD 21201 \\ E-mail:christianjkinney@gmail.com
}

\begin{abstract}
$\mu$-Crystallin is a NADPH-regulated thyroid hormone binding protein encoded by the CRYM gene in humans. It is primarily expressed in the brain, muscle, prostate, and kidney, where it binds thyroid hormones, which regulate metabolism and thermogenesis. It also acts as a ketimine reductase in the lysine degradation pathway when it is not bound to thyroid hormone. Mutations in $C R Y M$ can result in non-syndromic deafness, while its aberrant expression, predominantly in the brain but also in other tissues, has been associated with psychiatric, neuromuscular, and inflammatory diseases. CRYM expression is highly variable in human skeletal muscle, with $15 \%$ of individuals expressing $\geq 13$ fold more CRYM mRNA than the median level. Ablation of the Crym gene in murine models results in the hypertrophy of fast twitch muscle fibers and an increase in fat mass of mice fed a high fat diet. Overexpression of Crym in mice causes a shift in energy utilization away from glycolysis towards an increase in the catabolism of fat via $\beta$-oxidation, with commensurate changes of metabolically involved transcripts and proteins. The history, attributes, functions, and diseases associated with CRYM, an important modulator of metabolism, are reviewed.
\end{abstract}

Key words: CRYM, $\mu$-Crystallin, mu-crystallin, thyroid hormone, $T_{3}, T_{4}$, ketimine reductase

Thyroid hormones (THs) are essential regulators of gene expression and metabolism and their precise control is therefore crucial to maintaining homeostasis and adapting to different environmental conditions. TH regulation is achieved at many levels and through multiple means, including synthesis, secretion, uptake into tissues, intracellular processing by deiodinases, and potentially binding to proteins involved in intracellular storage. Here, we review the TH binding protein, $\mu$-crystallin $(C R Y M)$, that may play a key role in the latter process, intracellular sequestration and storage.

$\mathrm{T}_{3}$ and $\mathrm{T}_{4}$ thyroid hormone ( $\left.\mathrm{TH}\right)$ are produced in the thyroid, though the thyroid primarily produces $\mathrm{T}_{4}$ and less than $20 \%$ of the $\mathrm{TH}$ it releases is $\mathrm{T}_{3}$ (Abdalla and Bianco 2014). Triiodothyronine $\left(\mathrm{T}_{3}\right)$ is primarily produced peripherally in the body via the monodeiodination of thyroxine $\left(\mathrm{T}_{4}\right)$ (Chopra 1977). THs typically act as transcription factors by binding to thyroid hormone receptors (TRs). $\mathrm{T}_{3}$ has a 10 -fold higher affinity for TRs than $\mathrm{T}_{4}$ and therefore, it is a more potent transcription factor (Abdalla and Bianco 2014). Liganded and unliganded TRs act as strong regulators of metabolism and thermogenic homeostasis (Larsen et al. 1981) primarily by affecting transcription of genes containing thyroid response elements (Brent 2012).

The ability to bind TH with high affinity suggests that $\mu$-crystallin may play a role in regulating $\mathrm{TH}$ levels by controlling the availability of $\mathrm{TH}$ to interact with receptors, with possible downstream consequences to physiology and metabolism. Reed et al. (2007) have observed on a 2D proteomic gel of skeletal muscle biopsies taken from 3 individuals with FSHD and 2 healthy individuals that $\mu$-crystallin showed increased expression and was the only differentially expressed protein in comparing individuals with facioscapulohumeral muscular dystrophy (FSHD) to healthy individuals (Reed et al. 2007). In order to study increased levels of skeletal muscle 
$\mu$-crystallin, which was at that time a candidate for the then unknown pathological protein in FSHD, they constructed a transgenic mouse specifically overexpressing $\mu$-crystallin in skeletal muscle, the Crym tg mouse. At the time, little was known about the pathological agent in FSHD, although Double Homeobox 4 (DUX4) is now widely believed to determine disease pathology (Tawil et al. 2014).

Crym tg mice were created to specifically overexpress $\mu$-crystallin in skeletal muscle by placing the mouse Crym open reading frame under the control of the human skeletal actin promoter (ACTA1) and the human slow troponin I enhancer (TNNI1). The transgenic plasmid incorporated randomly into intron 12 of the Cntn6 gene after oocyte injection. The resultant transgenic mice were bred to homozygosity to be used to measure the effects of high $\mu$-crystallin expression in skeletal muscle (Kinney et al. 2021).

\section{Discovery of $\mu$-Crystallin}

$\mu$-Crystallin was first identified in 1957 by Tata who called the protein a thyroxine-binding protein (Tata 1958). Hashizume et al. subsequently showed the same protein that they called Factor b, could bind $\mathrm{T}_{3}$ and $\mathrm{T}_{4}$ in the presence of NADH or preferably NADPH (Hashizume et al. 1986), the latter dinucleotide causing the increased binding capacity of cytosolic 3,5,3'-triiodo-L-thyronine $\left(\mathrm{T}_{3}\right)$-binding protein (CTBP), the next name for $\mu$-crystallin (Hashizume et al. 1989a). NADP bound to CTBP ( $\mu$-crystallin) enhanced the presence of $\mathrm{T}_{3}$ in the nucleus of rat kidney cells at sites that differed from other nuclear $\mathrm{T}_{3}$ sites (Hashizume et al. 1989b), whereas NADPH diminished the amount of nuclear $\mathrm{T}_{3}$ (Hashizume et al. 1989c). Maximal activation by NADP or NADPH was at concentrations of $0.1 \mu \mathrm{M}$ and $25 \mu \mathrm{M}$ respectively, 20 and 4 times less, respectively, than physiological levels (Hashizume et al. 1989d), suggesting that $\mu$-crystallin in cells was likely to be bound to both NADP and NADPH. CTBP was shown to increase cellular and nuclear uptake of $\mathrm{T}_{3}$ as well as decrease cellular and nuclear efflux of $\mathrm{T}_{3}$ in addition to suppressing expression of thyroid hormone responsive genes (Mori et al. 2002). Kobayashi et al. (1991) further characterized $\mu$-crystallin as a dimer of two identical 38,000 Da subunits. At the time, it was referred to as p38CTBP, to distinguish it from a $58 \mathrm{kDa}$ thyroxine-binding protein, p58CTBP (Hashizume et al. 1989a). Wistow and Kim (1991) gave $\mu$-crystallin its current name after they found the protein highly expressed in the lens of some marsupials. More recently, $\mu$-crystallin has been shown to function as a ketimine reductase in addition to its activity as a NADPH-regulated thyroid hormone binding protein (Hallen et al. 2011; Hallen et al. 2015a, b; Hallen and Cooper 2017).

\section{Temporospatial expression of CRYM}

$\mu$-Crystallin is predominantly expressed in the cerebral cortex, heart, skeletal muscle, prostate, and kidney (Thul et al. 2017). Temporally, Crym expression in mice gradually increases from embryonic day 10.5 until its zenith at embryonic day 14.5, when the brain and inner ear have the highest expression. Expression subsequently decreases gradually and falls sharply postnatally in most tissues. Some Crym expressing organs such as the renal medulla of the kidney increase in expression of Crym postnatally while other organs continue to express Crym, albeit at lower levels than in utero (Smith et al. 2019). CRYM mRNA in humans is expressed at its highest levels in the basal ganglia of the brain followed by the heart; at the protein level, $\mu$-crystallin is most highly expressed in the basal ganglia, cerebral cortex, kidney and prostate (data obtained from the normalized Consensus Dataset of the Human Protein Atlas) (Uhlen et al. 2015). Subcellularly, $\mu$-crystallin localizes to the cytosol (Kobayashi et al. 1991). In humans, $\mu$-crystallin is also expressed in the inner ear where two, rare mutations, X315Y and K314T, cause Deafness, Autosomal Dominant 40 (Abe et al. 2003). There are no other illnesses in which CRYM has been implicated, although it's aberrant expression has been associated with amyotrophic lateral sclerosis (Fukada et al. 2007; Daoud et al. 2011; Hommyo et al. 2018), facioscapulohumeral muscular dystrophy (FSHD) (Reed et al. 2007; Vanderplanck et al. 2011), endotoxin-induced uveitis (Imai et al. 2010), schizophrenia (Middleton et al. 2002; Miklos and Maleszka 2004), and Huntington's Disease (Francelle et al. 2015).

\section{Thyroid hormones and their receptors}

THs are crucial affecters of metabolism and thermogenesis, with $30 \%$ of resting energy expenditure under their control (Silva 2005). Significant changes in the levels of THs lead to illness. Hypothyroidism can cause depression, cardiovascular disease, fatigue and lethargy, and weight gain, among other consequences (Bello and Bakari 2012). Conversely, hyperthyroidism results in a wide range of largely distinct maladies, such as heart palpitations, fatigue, weight loss, and muscle weakness, among others (Mansou- 
rian 2010). Given their centrality to biological systems, the production of THs is under tight regulation.

Regulation and synthesis of thyroid hormones. $\mathrm{TH}$ production is governed by the HypothalamicPituitary-Thyroid axis (Mendoza and Hollenberg 2017). Thyrotropin-releasing hormone neurons located in the paraventricular nucleus of the hypothalamus control secretion of thyrotropin releasing hormone (TRH) in response to THs (Morley 1979; Yarbrough 1979), Agouti Related Peptide (AgRP) (Fekete et al. 2002), Neuropeptide Y (NPY) (Fekete et al. 2001), cocaine and amphetamine-regulated transcript (Serrano et al. 2014; Fekete et al. 2000), norepinephrine (Zimmermann et al. 2001), and leptin (Harris et al. 2001). These factors are directly and indirectly regulated by environmental stimuli such as cold exposure (Sotelo-Rivera et al. 2017), teat suckling (Sanchez et al. 2001), and shortage of food (Legradi et al. 1997; Mihaly et al. 2000) and the TH feedback loop, among other factors (RodriguezRodriguez et al. 2019).

Upon secretion of TRH by the hypothalamus, the hormone enters fenestrated primary portal capillaries connected to the anterior pituitary pars distalis (Rodriguez-Rodriguez et al. 2019). TRH binding to its receptor (TRH receptor 1) in the anterior pituitary induces the synthesis and release of thyroid stimulating hormone (TSH) (Snyder and Utiger 1972; Heuer et al. 2000). TSH then travels via the bloodstream to the thyroid gland where it binds TSH receptors (Schaefer and Klein 2011). This binding promotes the synthesis and release of the THs, $\mathrm{T}_{3}$ and $\mathrm{T}_{4}$. Approximately $80 \%$ of $\mathrm{TH}$ produced by the thyroid gland are $\mathrm{T}_{4}$ (Pirahanchi et al. 2000) while $80 \%$ of $\mathrm{T}_{3}$ comes from the peripheral deiodination of $\mathrm{T}_{4}$ (Schimmel and Utiger 1977), with the remaining $\mathrm{T}_{3}$ fraction generated by the intrathyroidal deiodination of $\mathrm{T}_{4}$ and by the direct synthesis of $\mathrm{T}_{3}$ within the thyroid gland itself (Deme et al. 1975; Kubota et al. 1984). $T_{3}$ and $T_{4}$ then travel via the bloodstream to peripheral organs, where they are taken up.

Thyroid hormone transport. THs are transported into cells primarily by SLC16A2 (MCT8), SLC16A10 (MCT10), and SLCO1C1 (OATP1C1), which are largely specific transporters for $\mathrm{T}_{3}$ and $\mathrm{T}_{4}$ (Visser et al. 2011). THs are also transported through more broadly acting transporters as well, such as SLC10A1 (Friesema et al. 1999; Visser et al. 2010), $A B C B 1$ (efflux) (Mitchell et al. 2005), SLC7A5 and SLC3A2 (LAT1 and 4F2hc respectively, acting as a heterodimer), SLC7A 8 and SLC3A2 (LAT2 and 4F2hc respectively, acting as a heterodimer) (Jansen et al. 2005), and thirteen organic anion transporting polypeptides (OATP) (Jansen et al. 2005). Once in the cell, deiodinases remove one or more iodine atoms from $\mathrm{T}_{4}$ or $\mathrm{T}_{3}$ to convert $\mathrm{T}_{4}$ into $\mathrm{T}_{3}$ or reverse $\mathrm{T}_{3}\left(\mathrm{rT}_{3}\right) . \mathrm{T}_{3}$ and $\mathrm{rT}_{3}$ can be converted into $\mathrm{T}_{2}$. Deiodinase 1 (DIO1) is responsible for the production of $\mathrm{T}_{3}, \mathrm{rT}_{3}$, and $\mathrm{T}_{2}$. Deiodinase 2 (DIO2) produces $\mathrm{T}_{3}$ from $\mathrm{T}_{4}$, and $\mathrm{T}_{2}$ from $\mathrm{rT}_{3}$. Finally, deiodinase 3 (DIO3) is capable of producing $\mathrm{rT}_{3}$ and $\mathrm{T}_{2}$ from $\mathrm{T}_{4}$ and $\mathrm{T}_{3}$ respectively (Pihlajamaki et al. 2005; Williams and Bassett 2011). $\mathrm{rT}_{3}$ and $\mathrm{T}_{2}$ are largely inactive biologically (Beckett and Arthur 1994; Senese et al. 2014).

Thyroid receptors. In mammals, THs, primarily in the form of $\mathrm{T}_{3}$, bind to nuclear TRs al (Sap et al. 1986; Weinberger et al. 1986), $\beta 1$ (Jhanwar et al. 1985), $\beta 2$ (Hodin et al. 1989), $\beta 3$ [rodent only] (Williams 2000 ), and $\beta 4$ (Tagami et al. 2010). $\mathrm{T}_{3}$ can also bind to mitochondrial TRs p 43 (Casas et al. 1999) and p28 (Sterling et al. 1984), and to the plasma membrane TR p30 TRa1 (Kalyanaraman et al. 2014). A number of additional isoforms of the TR subunits can be generated through alternative splicing of the THRA and THRB genes, including $\triangle \alpha 1, \Delta \alpha 2$ (Chassande et al. 1997), $\alpha 2, \alpha 3, \alpha \Delta \mathrm{E} 6$ (Pantos and Mourouzis 2018), and $\Delta \beta 3$ [rodent only] (Williams 2000). These do not bind $\mathrm{TH}$ and most instead act in a dominant negative fashion, competing against $\mathrm{TH}$ bound TRs for TRE sites in the genome (O'Shea and Williams 2002; Casas et al. 2006; Raparti et al. 2013; Watanabe and Weiss 2018).

$\mathrm{T}_{3}$ binds to TRs with a $\mathrm{K}_{\mathrm{D}}=0.06 \mathrm{nM}$. $\mathrm{T}_{4}$ can also bind to thyroid hormone receptors, though with a much lower affinity, $\mathrm{K}_{\mathrm{D}}=2 \mathrm{nM}$ (Sandler et al. 2004). $\mathrm{TH}$ binding to TRs alters the conformation of the protein affecting its ability to bind DNA (Apriletti et al. 1998). TRs act as transcriptional regulators as ligand-bound or unbound monomers, homodimers, heterotrimers, homotrimers (Mengeling et al. 2005), or most commonly as heterodimers with retinoid X receptors (RXR) (Velasco et al. 2007). TRs bind to thyroid hormone response elements (TREs), sequences in the genome that regulate transcription of associated genes. There are three consensus TRE sequences: direct repeat 4 (DR4) AGGTCAnnnnAGGTCA, a palindrome AGGTCATGACCT, and an inverted palindrome with a 6 base pair gap (IP6) TGACCTnnnnnnAGGTCA (Liu et al. 2020). Both unliganded and ligand-bound TRs can bind TREs to repress or promote transcription (Graupner et al. 1989). Some TRE sites are bound by unliganded $\mathrm{TR}$ and prevent transcription until $\mathrm{TH}$ binds to 
the receptor, while some TRE sites are repressed by TH-bound TR. The same is true with TRs acting as transcriptional activators (Eckey et al. 2003). There are many different ways activation or repression of gene expression can occur through the multitude of THs, TRs, RXRs, TREs, and various combinations thereof. The diversity of mechanisms by which THs can act through TRs, RXRs and TREs may help explain its ability to regulate so many different cellular and bodily functions and physiology, and why regulation of the unifying factor, $\mathrm{TH}$, is so important.

$\boldsymbol{\mu}$-Crystallin (CRYM). CRYM, the gene encoding CRYM mRNA and the $\mu$-crystallin protein, is located at $16 \mathrm{p} 12.2$ in the human genome. The gene is $64.2 \mathrm{~kb}$ long, encoding a protein of 314 amino acids with a calculated molecular mass of $33.8 \mathrm{kD}$. Similarly, in mice, the Crym gene is located at $7 \mathrm{qF} 2$, is $15.7 \mathrm{~kb}$ long, and encodes a 313 amino acid protein, with a calculated molecular mass of $33.5 \mathrm{kD}$. $\mu$-Crystallin binds strongly to $\mathrm{T}_{3}$ with a $\mathrm{K}_{\mathrm{D}}=0.3 \mathrm{nM}$ (Beslin et al. 1995) [see also Hallen et al. 2015a]. The crystal structure of mouse $\mu$-crystallin has been solved to $1.75 \AA$. Five residues in the protein form a potassium ion binding pocket: Leu130, Gly219, Cys283, Lys285, and Thr287 (Borel et al. 2014). $\mathrm{T}_{3}$ binds to murine $\mu$-crystallin through the hydrophobic interactions of Phe58, Phe79, and Val49 as well as Arg229. Ser228 and Arg47 form hydrogen bonds with $\mathrm{T}_{3}$. Finally, Lys75, Arg118, Ser228, and Leu292 interact with $\mathrm{T}_{3}$ through water molecules (Borel et al. 2014).

$\boldsymbol{\mu}$-Crystallin in animals. $\mu$-Crystallin may play a role in adapting metabolism to meet the specific energetic requirements determined by genetic and environmental factors. Joshi et al. showed in 2017 that the sleeping breath rate of female Crym knockout (KO) mice was higher than controls (Joshi et al. 2019). Serum $\mathrm{T}_{3}$ and $\mathrm{T}_{4}$ concentrations are decreased while influx and efflux of $\mathrm{T}_{3}$ is increased in Crym $\mathrm{KO}$ mice (Suzuki et al. 2007). It's possible that Crym KO mice have higher levels of anaerobic glycolysis due to lower levels of free cytoplasmic TH, causing an increased buildup of lactate, which may be indirectly cleared by a higher breath rate (Ducros and Trippenbach 1991). Indeed, Crym KO mice had hypertrophy of glycolytic fast twitch Type IIb muscle fibers (Seko et al. 2016) and when Crym KO mice were placed on a high fat diet they had increased fat mass as assayed by computer tomography compared to control mice on the same diet (Ohkubo et al. 2019).

$\mu$-Crystallin appears to play an important role in environmental and metabolic adaptation in other mammals as well. CRYM levels in the hypothalamus of dogs are significantly lower than in the hypothalami of wolves and coyotes (Saetre et al.2004). This may be a difference in regulation of TRH production since TRH is produced in the hypothalamus which ultimately causes the production of $\mathrm{TH}$. TH in the hypothalamus acts in a negative feedback loop to inhibit the production of TRH (Fekete and Lechan 2007). Lower levels of CRYM in the hypothalami of dogs may allow for greater inhibitory effects of $\mathrm{TH}$ on TRH production, reflecting adaptation to differences in food availability and shelter of domesticated dogs versus wolves and coyotes. Mukai et al. (2009) used microarrays and qPCR to measure decreased levels of CRYM in the hypothalamus of song sparrows in autumn compared to spring, possibly implicating $\mu$-crystallin again in controlling metabolic rate in relation to seasonal changes and the availability of food. Hinaux noted polymorphisms present in crym in Astyanax mexicanus surface fish compared to the same species of fish that dwell in caves devoid of any light and plentiful food sources (Hinaux et al. 2015). Curiously, the skeletal muscles of the cavefish are resistant to insulin, and the fish have a lower metabolic rate and higher percent of body fat than their surface-dwelling cousins (Ojha and Watve 2018). Chinese Erhualian pigs express 16-26 times more CRYM in their subcutaneous fat than in their visceral fat (intramuscular, retroperitoneal, and mesenteric adipose tissue) and CRYM is one of only seven genes specifically enriched in subcutaneous fat compared to visceral fat pads (Liu et a. 2019). Similarly, humans express 2.6-3.0 times more CRYM in their subcutaneous fat compared to their visceral fat (Serrano et al. 2014). Taken together, these observations suggest that $\mu$-crystallin may play a role in the metabolic adaptation of organisms to the energy requirements and food availability in their environments.

$\boldsymbol{\mu}$-Crystallin as a ketimine reductase. Although $\mu$-Crystallin accounts for approximately a quarter of total lens protein in some Australian marsupials, the protein does not share sequence homology with other crystallins (Wistow and Kim 1991). Rather, mammalian $\mu$-crystallin shares $31-33 \%$ amino acid sequence identity with bacterial ornithine cyclodeaminases (Kim et al. 1992) and 30\% sequence identity with archaeal AF1665 AlaDH (Gallagher et al. 2004), suggesting a potential role for $\mu$-crystallin in amino acid metabolism. Consistent with this, $\mu$-crystallin is a ketimine reductase and uses both $\mathrm{NADH}$ and NADPH as a cofactor (Hallen et al. 2011). $\mu$-Crystallin acts on naturally occurring ketimines present in lysine 
degradation, $\Delta^{1}$-piperideine-2-carboxylate (P2C) and an analog of P2C, $\Delta^{1}$-pyrroline-2-carboxylate (Pyr2C), at neutral $\mathrm{pH}$ (7.2) and more efficiently at an acidic pH (5.0) (Hallen et al. 2011; Hallen et al. 2015a, b; Hallen and Cooper 2017). Interestingly, $\mu$-crystallin's activity as a ketimine reductase is competitively inhibited by sub-nanomolar concentrations of $\mathrm{T}_{3}$ and $\mathrm{T}_{4}$, with $\mathrm{K}_{\mathrm{I}}=0.60 \mathrm{nM}$ and $\mathrm{K}_{\mathrm{I}}=0.75$ $n M$, respectively (compared to $T_{3}$, which binds with a $K_{D}=0.3 \mathrm{nM}$ ) (Beslin et al. 1995). $\mathrm{T}_{2}$ and $\mathrm{rT}_{3}$ only minimally inhibit $\mu$-crystallin (Hallen et al. 2015). $\mu$-Crystallin has been proposed to play a role in the pipecolate pathway, the dominant lysine degradation pathway in the brain, as opposed to the saccharopine pathway, which breaks down lysine in the rest of the body (Hallen and Cooper 2017).

\section{CRYM and disease}

CRYM expression in the brain. Crym is highly specific to certain regions and cell types in the brain. Kim et al. (1992) were the first to measure $\mu$-crystallin in the brain of kangaroo and humans in 1992. Arlotta et al. (2005) identified $\mu$-crystallin expression in some corticospinal motor neurons and subcerebral neurons of layer $\mathrm{V}$ of the cerebral cortex. There is increased staining of $\mu$-crystallin in the hippocampus with higher expression distal to the dentate gyrus of mice, and gradually diminishing proximally (Lein et al. 2007). Fink et al. (2015) showed $\mu$-crystallin expression in the cortex to be limited to spinally projecting corticospinal motor neurons, and not in layer $\mathrm{V}$ neurons sending projections either intracortically or corticofugally. They also documented $\mu$-crystallin in the dorsal, lateral, and ventral funiculi of the cervical and lumbar spinal cord and spinal gray matter of mice.

CRYM mRNA in man is expressed in most areas of the brain assessed by GTEx (amygdala, anterior cingulate cortex, caudate, cerebellar hemisphere, cerebellum, cortex, frontal cortex, hippocampus, nucleus acumbens, putamen) but not in the substantia nigra or the spinal cord (GTEx Consortium 2013). The absence of CRYM mRNA in human spinal cord does not agree with the findings of Fink et al. (2015) in mice. This incongruency may be due to a difference in species, condition, or due to temporal expression of mRNA versus protein. At the mRNA level the nucleus acumbens expresses the most CRYM (GTEx Consortium 2013). Because labeling for $\mu$-crystallin can clearly delineate the neuronal structures in the brain many researchers use its expression as a regional marker.
Huntington's disease. $\mu$-Crystallin's increased presence and function in the brain may have implications for disease. CRYM expression is significantly decreased in human caudate nucleus and cerebellum in individuals with Huntington's disease (Hodges et al. 2006). Crym also shows decreased expression in the brains of R6/2, BACHD, and Knock-In 140 CAG mice (Brochier et al. 2008; Francelle et al. 2015), murine models of Huntington's disease, and may play a neuroprotective role in striatal medium-size spiny neurons in Huntington's disease (Francelle et al. 2015).

Amyotrophic Lateral Sclerosis. $\mu$-Crystallin has also been associated with amyotrophic lateral sclerosis (ALS). In a mouse model of familial ALS, SOD1 ${ }^{\text {L126delTT }}$, Crym shows an approximately 26 -fold increase in expression in the spinal cord from presymptomatic to post-symptomatic mice (Fukada et al. 2007). Two mutations, R169C and H16P, in CRYM have been associated with sporadic ALS (Daoud et al. 2011); a recurrent mutation has also been identified in a mixed pool of familial and sporadic ALS patients (Pensato et al. 2020). The human CRYM gene is approximately $2.7 \mathrm{Mb}$ away from a $37.8 \mathrm{Mb}$ locus with genetic linkage to familial ALS (Sapp et al. 2003). $\mu$-Crystallin progressively decreases in expression in the pyramidal tracts in ALS patients, in a mosaic expression pattern and leading to its total absence in the distal regions of the pyramidal tract (e.g., lateral and anterior corticospinal tracts of the spinal cord). Hommyo et al. (2018) suggest that this expression pattern may reflect the "dying back" phenomenon, in which progressive neurodegeneration begins with more distal tissues and axons. In addition, miR-155 and miR-142, predicted to be regulators of CRYM, are increased in the spinal cord of individuals with sporadic ALS (Figueroa et al. 2016).

Schizophrenia. Individuals with schizophrenia show decreased CRYM in Brodmann area (BA) 9 of the dorsal prefrontal cortex (PFC) (Middleton et al. 2002; Arion et al. 2007), as well as BA 46 of the PFC at the mRNA (Martins-de-Souza et al. 2009a) and protein level (Martins-de-Souza et al. 2009b). Martins-de-Souza et al. (2010) reported the decreased expression of $\mu$-crystallin in the mediodorsal thalamus of the brain in individuals with schizophrenia as well as a negative correlation between $\mu$-crystallin levels and duration of the disease. By contrast, Hakak et al. (2001) reported increased levels of CRYM in BA 46 of the PFC in individuals with schizophrenia. $\mu$-Crystallin also increases in the corpus callosum of 
individuals with schizophrenia (Sivagnanasundaram et al. 2007).

CRYM is not implicated broadly in many neurologic disorders, however. For example, no associations between major depressive disorder or bipolar disorder have been observed (Johnston-Wilson et al. 2000; Beasley et al.2006).

CRYM as a potential therapeutic for psychiatric disorders. CRYM appears to play an important, though yet unknown, role in the brain. Walker et al. (2020) show that Crym overexpression in the medial amygdala of adult mice can recapitulate the transcriptional and behavioral effects of adolescent social isolation. Amazingly, social isolation of adult mice does not result in these same changes, suggesting that Crym overexpression in the medial amygdala of adult mice can revert the brain to a more plastic state associated with adolescence (Walker et al. 2020). This raises the eventual possibility, though technically still unachievable, that overexpressing CRYM in human medial amygdala could be used to reprogram individuals to become more resilient to some psychiatric disorders (Walker et al. 2020).

CRYM and non-syndromic deafness. Autosomal dominant deafness-40 (DFNA40), a non-syndromic deafness in man, is the only disease that is currently known to be caused by mutations in CRYM. It is not associated with any intellectual, structural or other dysfunctions. Two heterozygous mutations were identified at the C-terminus of $\mu$-crystallin, X315Y and $\mathrm{K} 314 \mathrm{~T}$. The K314T mutation segregated in an autosomal dominant fashion, while the $\mathrm{X} 315 \mathrm{Y}$ mutation was a de novo change (Abe et al. 2003). A third heterozygous mutation, P51L was later found to associate with DFNA40. This mutation also segregates in an autosomal dominant fashion, further confirming the inheritance pattern of DFNA40 (Wang et al. 2020). The severity of hearing loss varies with the mutations noted above. Moderate bilateral hearing impairment (50-60 dB) has been observed in the individual with the $\mathrm{X} 315 \mathrm{Y}$ mutation, starting at 19 months of age and progressing to a hearing loss of 70 $\mathrm{dB}$ by age 13 . Individuals with the $\mathrm{K} 314 \mathrm{~T}$ show severe bilateral hearing loss $(80-90 \mathrm{~dB})$ starting at 1 year old, with no further progression (Abe et al. 2003). Individuals with the P51L mutation have moderate to severe hearing loss $(50-110 \mathrm{~dB})$ without progression, though only one individual was followed for 4 years (Wang et al. 2020).

Correlating these auditory changes with changes in the activities of $\mu$-crystallin is challenging. The X315Y mutation in $\mu$-crystallin showed a similar binding affinity to $\mathrm{T}_{3}$ as wild type $\mu$-crystallin, but the K314T mutation in $\mu$-crystallin was unable to bind to $T_{3}$ at all (Oshima et al. 2006). When expressed in COS-7 cells, the X315Y mutation in $\mu$-crystallin localizes to vacuoles and the $\mathrm{K} 314 \mathrm{~T}$ mutation in $\mu$-crystallin localizes perinuclearly, in contrast to the wild type protein, which is cytoplasmically distributed (Abe et al. 2003). Although CRYM-X315Y can bind $\mathrm{T}_{3}$, its sequestration in vacuoles may reduce its access to cytoplasmic THs. Alternatively, these $\mu$-crystallin mutants may affect potassium ion recycling of the endolymph, a function of lateral fibrocytes of the spiral ligaments and the spiral limbus fibrocytes, where Crym is highly expressed (Abe et al. 2003)

\section{Genetics of CRYM}

CRYM has a mutation rate of $10^{-4.9127}$ mutations per chromosome (Samocha et al. 2014), which is outside of the definition of a constrained gene (Samocha et al. 2014), i.e. a gene in which mutations are likely deleterious and result in their negative selection and removal from the gene pool. Congruent with the mutation rate, there are 209 "common" mutations (variants with a minor allele frequency [MAF] of at least 1\%) in the 1000 Genomes Phase 3 dataset (www. internationalgenome.org/data). However, there is only one common exonic variant, rs34045013, a synonymous mutation in exon 8 . Rs 34045013 is only a common variant in African populations; its MAF does not rise to a frequency of $1 \%$ in European, East Asian, South Asian, or American populations in the 1000 Genomes Phase 3 dataset, though it is a common variant in the African American population examined in the GO Exome Sequencing Project (Tennessen et al. 2012). To the best of our knowledge, there are no CRYM null individuals. One individual has been identified with copy number loss of one chromosome [GRCh37/hg19 16p12.2(chr16:21313377-21947230)x1] where exon 1 of CRYM transcript variant 1 (RefSeq ID: NM_001888.5), the longer of the two CRYM variants observed in humans, is lost. A second individual shows a homozygous deletion [GRCh37/ hg19 16p12.2(chr16:21300997-21308651)x0] of either intron 1 of CRYM transcript variant 1, or the putative promoter/upstream region of CRYM transcript variant 2 (RefSeq ID: NM_001376256.1). In contrast to the absence of CRYM null individuals, there are 22 individuals with a CRYM copy number gain (3 copies as opposed to the normal 2 [diploid] copies) and one individual with maternal uniparental disomy without copy number change in NCBI ClinVar. 
Rs3848259 is a "common" variant that occurs in the 5' untranslated region (UTR) of CRYM transcript variant 1 and is upstream of CRYM transcript variant 2. Rs3848259 is present in approximately $24.8 \%$ of the European population while being present in only $5.0 \%$ of the African population according to data from the ALFA Project (Phan et al. 2020). Furthermore, rs3848259 is located in a DNase hypersensitive region (Miga et al. 2015), a ZIC3 and ZNF341 transcription factor binding site (Fornes et al. 2020), and a CpG island (Gardiner-Garden and Frommer 1987). Rs3848259 alters one of the two most conserved base pairs in the DNA binding sequence motif of ZIC3, CCE(C/T)GCTGGG (Ahmed et al. 2020) (underlined), from a cytosine to a guanine. This may inhibit the transcription factor ZIC3 from binding to the 5'UTR/genic upstream region potentially affecting transcription of CRYM. In one of the two consensus DNA binding motifs in ZNF341, rs3848259 affects a non-conserved base pair in the sequence, TGGAACAGCCNC (underlined) (Beziat et al. 2018; FreyJakobs et al. 2018).

Because it is located in an epigenetically active region in the 5'UTR of CRYM transcript variant 1 and upstream of CRYM transcript variant 2, rs3848259 and its effects on ZIC3 and ZNF341 binding may alter transcription of CRYM in the approximately $25 \%$ of individuals of European descent and 5\% of individuals of African descent in whom this common variant is found. Humans display a wide range of expression of CRYM in skeletal muscle. In 803 transcriptomes in GTEx Analysis V8, CRYM levels vary from 0 transcripts per million (TPM) to $39.1 \mathrm{TPM}$ with a median of 0.1584 TPM. Most people express little to no CRYM in their skeletal muscle, yet $15.44 \%$ express 2 TPM of CRYM or more, and $5.85 \%$ of people express CRYM at levels of 10 TPM or greater (GTEx Consortium 2013). SNPs like rs3848259 as well as other factors may play a role in the large degree of heterogeneity of CRYM expression seen skeletal muscle.

\section{Effects of high Crym expression}

$\mu$-Crystallin has been shown to modulate $\mathrm{TH}$ levels. Precise control of $\mathrm{TH}$ levels is crucial to physiology and metabolism. Serious diseases can arise from inadequate or overabundant levels of TH. Nevertheless, the most abundant tissue in humans, skeletal muscle, displays a wide range of CRYM levels (GTEx Consortium 2013). What effects does $\mu$-crystallin have in individuals who express high levels of $\mu$-crystallin? Kinney et al. explored this question with a transgenic murine model that specifically overexpresses Crym in skeletal muscle (Kinney et al. 2021).

Along with a 27.5- to 154-fold increase of Crym mRNA and a 2.6 - to 147.5 -fold increase of $\mu$-crystallin protein, depending on which skeletal muscle was assayed, Kinney et al. (2021) observed a 192-fold increase in $\mathrm{T}_{3}$ in extracts of tibialis anterior (TA) muscle and a 1.2-fold decrease of serum $\mathrm{T}_{4}$ in Crym tg mice compared to control mice. Both changes were significant. The large increase in intramuscular $\mathrm{T}_{3}$ due to the increased expression of Crym may be the cause for some of the phenotypes they observed in Crym tg mice.

Crym tg mice have a decreased respiratory exchange ratio (RER), a metric that can be used to discriminate between carbohydrates and fat as energy sources (Lusk 1924). This decreased RER in Crym tg mice corresponds to a $13.7 \%$ shift towards increased utilization of fat as an energy source compared to controls. Consistent with this, gene ontology (GO) enrichment analysis of RNA-seq transcriptomic and LC.MS/MS proteomic data revealed significantly enriched ontological terms involving metabolism and muscle contraction. Kinney et al. (2021) found that almost all fiber types in Crym tg mouse soleus (but not TA) muscle had a smaller minimum Feret's diameter. Other groups have shown that slow twitch muscles like the soleus (Close 1965) mostly utilize $\beta$-oxidation of fat as opposed to fast twitch muscles that primarily utilize glycolysis of carbohydrates (Kalmar et al. 2012) and have smaller fiber sizes (Schiaffino and Reggiani 2011). Thyrotoxic doses of TH cause shifts in slow twitch mouse soleus, but not in fast twitch extensor digitorum longus (Freake and Oppenheimer 1995) muscle towards faster twitch characteristics such as shortened isometric twitch duration and increased rate of tension development (Fitts et al. 1984). By these metrics, TH has a greater impact on slow twitch muscle than fast twitch muscle. Taken together, the shift in metabolism from glycolytic towards $\beta$-oxidative in Crym tg mice, the concomitant GO terms at the transcriptomic and proteomic level, and the smaller soleus muscle fibers and the unchanged fiber sizes in fast twitch TA in the TH rich muscle of Crym tg mice all point towards $\mu$-crystallin shifting the metabolic and morphologic state of the muscle through the regulation of TH. Although this is difficult to reconcile with the fact that most muscle fibers in mice are fast twitch, a large proportion of them are also oxidative (i.e., Type IIA) and thus may be subject to the same shifts in gene regulation and morphology induced by Crym and $\mathrm{T}_{3}$ as soleus.

Although Crym tg mice show significant alterations in metabolism, transcripts and proteins 
expressed, and fiber size of slow twitch muscle, Crym tg mice do not show significant differences compared to controls in a number of physiologic tests including: specific isometric force of contraction, maximal rate of twitch force contraction/relaxation, grip strength, maximum treadmill running speed, and voluntary distance run. Fiber type as assayed by immunohistochemistry of myosin heavy chains, weight of most muscles and fat pads, diameter of TA muscle, percent of centrally nucleated fibers, voltage-induced $\mathrm{Ca}^{2+}$ transients, maximal amplitudes of transients and transient decay rates, total number of muscle fibers, and intramuscular fat were also unchanged compared to control mice (Kinney et al. 2021). Crym therefore appears to play an important but subtle role in skeletal muscle, through a mechanism that remains unknown.

\section{Conclusions}

$\mu$-Cystallin binds thyroid hormones and can act as a ketimine reductase in the brain when unbound by TH. As demonstrated by a number of studies, $\mu$-crystallin plays a crucial role in regulating the availability and level of thyroid hormone. Consequently, it's of no surprise that $\mu$-crystallin expression is tightly regulated both temporally and spatially. When mutated at particular moieties, $\mu$-crystallin becomes less active or mislocalized, leading to nonsyndromic deafness, DFNA40. Inappropriate expression of CRYM may be involved in several neurologic disorders as well. Despite this tight regulation in many tissues, men and women can express a wide range of CRYM in their skeletal muscle. The regulatory elements that lead to this difference are still unknown, and the physiological consequences to humans with high vs. low levels of muscle CRYM are still unclear. Our studies of transgenic mice that express high levels of muscle $\mu$-crystallin suggest that the physiological consequences are significant but subtle, with perhaps the most intriguing result indicating a change in the use of fat $v$ s. carbohydrate as an energy source. For now, however, CRYM's physiological role in man remains to be determined. Future studies will help define its function at the cellular, tissue and system levels.

\section{References}

Abdalla SM, Bianco AC. Defending plasma T3 is a biological priority. Clin Endocrinol (Oxf) 81, 633-641, 2014.

Abe S, Katagiri T, Saito-Hisaminato A, Usami S, Inoue Y, Tsunoda T, Nakamura Y. Identification of CRYM as a candidate responsible for nonsyndromic deafness, through cDNA microarray analysis of human cochlear and vestibular tissues. Am J Hum Genet 72, 73-82, 2003.

Ahmed JN, Diamand KEM, Bellchambers HM, Arkell RM. Systematized reporter assays reveal ZIC protein regulatory abilities are Subclass-specific and dependent upon transcription factor binding site context. Sci Rep 10, $13130,2020$.

Apriletti JW, Ribeiro RC, Wagner RL, Feng W, Webb P, Kushner PJ, West BL, Nilsson S, Scanlan TS, Fletterick RJ, Baxter JD. Molecular and structural biology of thyroid hormone receptors. Clin Exp Pharmacol Physiol Suppl 25, S2-S11, 1998.

Arion D, Unger T, Lewis DA, Levitt P, Mirnics K. Molecular evidence for increased expression of genes related to immune and chaperone function in the prefrontal cortex in schizophrenia. Biol Psychiatry 62, 711-721, 2007.

Arlotta P, Molyneaux BJ, Chen J, Inoue J, Kominami R, Macklis JD. Neuronal subtype-specific genes that control corticospinal motor neuron development in vivo. Neuron 45, 207-221, 2005.

Beasley CL, Pennington K, Behan A, Wait R, Dunn MJ, Cotter D. Proteomic analysis of the anterior cingulate cortex in the major psychiatric disorders: evidence for disease-associated changes. Proteomics 6, 3414-3425, 2006.

Beckett GJ, Arthur JR. 3 The iodothyronine deiodinases and 5'-deiodination. Baillière's clinical endocrinology and metabolism 8, 285-304, 1994.

Bello F, and Bakari A. Hypothyroidism in adults: A review and recent advances in management. J Diabetes Endocrinol 3, 57-69, 2012.

Beslin A, Vie MP, Blondeau JP, Francon J. Identification by photoaffinity labelling of a pyridine nucleotide-dependent tri-iodothyronine-binding protein in the cytosol of cultured astroglial cells. Biochem J 305, 729-737, 1995.

Beziat V, Li J, Lin JX, Ma CS, Li P, Bousfiha A, et al. A recessive form of hyper-IgE syndrome by disruption of ZNF341-dependent STAT3 transcription and activity. Sci Immunol 3, eaat4956, 2018.

Borel F, Hachi I, Palencia A, Gaillard MC, Ferrer JL. Crystal structure of mouse mu-crystallin complexed with NADPH and the T3 thyroid hormone. FEBS J 281, 1598-1612, 2014.

Brent GA. Mechanisms of thyroid hormone action. J Clin Invest 122, 3035-3043, 2012. 
Brochier C, Gaillard MC, Diguet E, Caudy N, Dossat C, Segurens B, Wincker P, Roze E, Caboche J, Hantraye P, Brouillet E, Elalouf JM, de Chaldee M. Quantitative gene expression profiling of mouse brain regions reveals differential transcripts conserved in human and affected in disease models. Physiol Genomics 33, 170-179, 2008.

Casas F, Rochard P, Rodier A, Cassar-Malek I, Marchal-Victorion S, Wiesner RJ, Cabello G, Wrutniak C. A variant form of the nuclear triiodothyronine receptor c-ErbAal plays a direct role in regulation of mitochondrial RNA synthesis. Mol Cell Biol 19, 7913-7924, 1999.

Casas F, Busson M, Grandemange S, Seyer P, Carazo A, Pessemesse L, Wrutniak-Cabello C, Cabello G. Characterization of a novel thyroid hormone receptor a variant involved in the regulation of myoblast differentiation. Mol Endocrinol 20, 749-763, 2006.

Chassande O, Fraichard A, Gauthier K, Flamant F, Legrand C, Savatier P, Laudet V, Samarut J. Identification of transcripts initiated from an internal promoter in the c-erbA alpha locus that encode inhibitors of retinoic acid receptor-alpha and triiodothyronine receptor activities. Mol Endocrinol 11, 1278-1290, 1997.

Chopra IJ. A study of extrathyroidal conversion of thyroxine (T4) to 3, 3', 5-triiodothyronine (T3) in vitro. Endocrinology 101, 453-463, 1977.

Close R. Force: velocity properties of mouse muscles. Nature 206, 718-719, 1965.

Daoud H, Valdmanis PN, Gros-Louis F, Belzil V, Spiegelman D, Henrion E, Diallo O, Desjarlais A, Gauthier J, Camu W, Dion PA, Rouleau GA. Resequencing of 29 candidate genes in patients with familial and sporadic amyotrophic lateral sclerosis. Arch Neuro 68, 587-593, 2011.

Deme D, Fimiani E, Pommier J, Nunez J. Free diiodotyrosine effects on protein iodination and thyroid hormone synthesis catalyzed by thyroid peroxidase. Eur J Biochem 51, 329-336, 1975.

Ducros G, Trippenbach T. Respiratory effects of lactic acid injected into the jugular vein of newborn rabbits. Pediatr Res 29, 548-552, 1991.

Eckey M, Moehren U, Baniahmad A. Gene silencing by the thyroid hormone receptor. Mol Cell Endocrinol 213, 13-22, 2003.

Fekete C, Mihaly E, Luo LG, Kelly J, Clausen JT, Mao Q, Rand WM, Moss LG, Kuhar M, Emerson CH, Jackson IM, Lechan RM. Association of cocaine- and amphetamine-regulated transcript-immunoreactive elements with thyrotropin-releasing hormone-synthesizing neurons in the hypothalamic paraventricular nucleus and its role in the regulation of the hypothalamic-pituitary-thyroid axis during fasting. J Neurosci 20, 9224-9234, 2000.

Fekete C, Kelly J, Mihaly E, Sarkar S, Rand WM, Legradi G, Emerson CH, Lechan RM. Neuropeptide Y has a central inhibitory action on the hypothalamic-pituitary-thyroid axis. Endocrinology 142, 2606-2613, 2001.

Fekete C, Sarkar S, Rand WM, Harney JW, Emerson CH, Bianco AC, Lechan RM. Agouti-related protein (AGRP) has a central inhibitory action on the hypothalamic-pituitary-thyroid (HPT) axis; comparisons between the effect of AGRP and neuropeptide Y on energy homeostasis and the HPT axis. Endocrinology 143, 3846-3853, 2002.

Fekete C, Lechan RM. Negative feedback regulation of hypophysiotropic thyrotropin-releasing hormone (TRH) synthesizing neurons: role of neuronal afferents and type 2 deiodinase. Front Neuroendocrinol 28, 97-114, 2007.

Figueroa-Romero C, Hur J, Lunn JS, Paez-Colasante X, Bender DE, Yung R, Sakowski SA, Feldman EL. Expression of microRNAs in human post-mortem amyotrophic lateral sclerosis spinal cords provides insight into disease mechanisms. Mol Cell Neurosci 71, 34-45, 2016.

Fink KL, Strittmatter SM, Cafferty WB. Comprehensive Corticospinal Labeling with mu-crystallin Transgene Reveals Axon Regeneration after Spinal Cord Trauma in ngr1-/- Mice. J Neurosci 35, 15403-15418, 2015.

Fitts RH, Brimmer CJ, Troup JP, Unsworth BR. Contractile and fatigue properties of thyrotoxic rat skeletal muscle. Muscle Nerve 7, 470-477, 1984.

Fornes O, Castro-Mondragon JA, Khan A, van der Lee R, Zhang X, Richmond PA, Modi BP, Correard S, Gheorghe M, Baranasic D, Santana-Garcia W, Tan G, Cheneby J, Ballester B, Parcy F, Sandelin A, Lenhard B, Wasserman WW, Mathelier A. JASPAR 2020: update of the open-access database of transcription factor binding profiles. Nucleic Acids Res 48, D87-D92, 2020.

Francelle L, Galvan L, Gaillard MC, Guillermier M, Houitte D, Bonvento G, Petit F, Jan C, Dufour N, Hantraye P, Elalouf JM, De Chaldee M, Deglon N, Brouillet E. Loss of the thyroid hormone-binding protein Crym renders striatal neurons more vulnerable to mutant huntingtin in Huntington's disease. Hum Mol Genet 24, 1563-1573, 2015.

Freake HC, Oppenheimer JH. Thermogenesis and thyroid function. Annu Rev Nutr 15, 263-291, 1995. 
Frey-Jakobs S, Hartberger JM, Fliegauf M, Bossen C, Wehmeyer ML, Neubauer JC, Bulashevska A, Proietti M, Frobel P, Noltner C, Yang L, Rojas-Restrepo J, Langer N, Winzer S, Engelhardt KR, Glocker C, Pfeifer D, Klein A, Schaffer AA, Lagovsky I, Lachover-Roth I, Beziat V, Puel A, Casanova JL, Fleckenstein B, Weidinger S, Kilic SS, Garty BZ, Etzioni A, Grimbacher B. ZNF341 controls STAT3 expression and thereby immunocompetence. Sci Immunol 3, eaat4941, 2018.

Friesema EC, Docter R, Moerings EP, Stieger B, Hagenbuch B, Meier PJ, Krenning EP, Hennemann G, Visser TJ. Identification of thyroid hormone transporters. Biochem Biophys Res Commun 254, 497-501, 1999.

Fukada Y, Yasui K, Kitayama M, Doi K, Nakano T, Watanabe Y, Nakashima K. Gene expression analysis of the murine model of amyotrophic lateral sclerosis: studies of the Leu126delTT mutation in SOD1. Brain Res 1160, $1-10,2007$.

Gallagher DT, Monbouquette HG, Schroder I, Robinson H, Holden MJ, Smith NN. Structure of alanine dehydrogenase from Archaeoglobus: active site analysis and relation to bacterial cyclodeaminases and mammalian mu crystallin. J Mol Biol 342, 119-130, 2004.

Gardiner-Garden M, Frommer M. CpG islands in vertebrate genomes. J Mol Biol 196, 261-282, 1987.

Graupner G, Wills KN, Tzukerman M, Zhang XK, Pfahl M. Dual regulatory role for thyroid-hormone receptors allows control of retinoic-acid receptor activity. Nature 340, 653-656, 1989.

GTEx Consortium. The Genotype-Tissue Expression (GTEx) project. Nat Genet 45, 580-585, 2013.

Hakak Y, Walker JR, Li C, Wong WH, Davis KL, Buxbaum JD, Haroutunian V, Fienberg AA. Genome-wide expression analysis reveals dysregulation of myelination-related genes in chronic schizophrenia. Proc Natl Acad Sci U S A 98, 4746-4751, 2001.

Hallen A, Cooper AJ, Jamie JF, Haynes PA, Willows RD. Mammalian forebrain ketimine reductase identified as $\mu$-crystallin; potential regulation by thyroid hormones. J Neurochem 118, 379-387, 2011.

Hallen A, Cooper AJ, Jamie JF, Karuso P. Insights into Enzyme Catalysis and Thyroid Hormone Regulation of Cerebral Ketimine Reductase/ $\mu$-Crystallin Under Physiological Conditions. Neurochem Res 40, 1252-1266, 2015a.

Hallen A, Cooper AJ, Smith JR, Jamie JF, Karuso P. Ketimine reductase/CRYM catalyzes reductive alkylamination of a-keto acids, confirming its function as an imine reductase. Amino Acids 47, 2457-2461, $2015 \mathrm{~b}$.

Hallen A, Cooper AJ. Reciprocal Control of Thyroid Binding and the Pipecolate Pathway in the Brain. Neurochem Res 42, 217-243, 2017.

Harris M, Aschkenasi C, Elias CF, Chandrankunnel A, Nillni EA, Bjøorbaek C, Elmquist JK, Flier JS, Hollenberg AN. Transcriptional regulation of the thyrotropin-releasing hormone gene by leptin and melanocortin signaling. J Clin Invest 107, 111-120, 2001.

Hashizume K, Kobayashi M, Miyamoto T. Active and inactive forms of 3,5,3'-triiodo-L-thyronine (T3)-binding protein in rat kidney cytosol: possible role of nicotinamide adenine dinucleotide phosphate in activation of T3 binding. Endocrinology 19, 710-719, 1986.

Hashizume K, Miyamoto T, Ichikawa K, Yamauchi K, Kobayashi M, Sakurai A, Ohtsuka H, Nishii Y, Yamada T. Purification and characterization of NADPH-dependent cytosolic 3,5,3'-triiodo-L-thyronine binding protein in rat kidney. J Biol Chem 264, 4857-4863, 1989a.

Hashizume K, Miyamoto T, Kobayashi M, Suzuki S, Ichikawa K, Yamauchi K, Ohtsuka H, Takeda T. Cytosolic 3,5,3'-triiodo-L-thyronine (T3)-binding protein (CTBP) regulation of nuclear T3 binding: evidence for the presence of T3-CTBP complex-binding sites in nuclei. Endocrinology 124, 2851-2856, $1989 \mathrm{~b}$.

Hashizume K, Miyamoto T, Yamauchi K, Ichikawa K, Kobayashi M, Ohtsuka H, Sakurai A, Suzuki S, Yamada T. Counterregulation of nuclear 3,5,3'-triiodo-L-thyronine (T3) binding by oxidized and reduced-nicotinamide adenine dinucleotide phosphates in the presence of cytosolic T3-binding protein in vitro. Endocrinology 124, 1678-1683, 1989c.

Hashizume K, Miyamoto T, Ichikawa K, Yamauchi K, Sakurai A, Ohtsuka H, Kobayashi M, Nishii Y, Yamada T. Evidence for the presence of two active forms of cytosolic 3,5,3'-triiodo-L-thyronine (T3)-binding protein (CTBP) in rat kidney. Specialized functions of two CTBPs in intracellular T3 translocation. J Biol Chem 264, 4864-4871, 1989d.

Heuer H, Schafer MK, O’Donnell D, Walker P, Bauer K. Expression of thyrotropin-releasing hormone receptor 2 (TRH-R2) in the central nervous system of rats. J Comp Neurol 428, 319-336, 2000.

Hinaux H, Blin M, Fumey J, Legendre L, Heuzé A, Casane D, Rétaux S. Lens defects in Astyanax mexicanus Cavefish: evolution of crystallins and a role for alphaA-crystallin. Dev Neurobiol 75, 505-521, 2015. 
Hodges A, Strand AD, Aragaki AK, Kuhn A, Sengstag T, Hughes G, Elliston LA, Hartog C, Goldstein DR, Thu D, Hollingsworth ZR, Collin F, Synek B, Holmans PA, Young AB, Wexler NS, Delorenzi M, Kooperberg C, Augood SJ, Faull RL, Olson JM, Jones L, Luthi-Carter R. Regional and cellular gene expression changes in human Huntington's disease brain. Hum Mol Genet 15, 965-977, 2006.

Hodin RA, Lazar MA, Wintman BI, Darling DS, Koenig RJ, Larsen PR, Moore DD, Chin WW. Identification of a thyroid hormone receptor that is pituitary-specific. Science 244, 76-79, 1989.

Hommyo R, Suzuki SO, Abolhassani N, Hamasaki H, Shijo M, Maeda N, Honda H, Nakabeppu Y, Iwaki T. Expression of CRYM in different rat organs during development and its decreased expression in degenerating pyramidal tracts in amyotrophic lateral sclerosis. Neuropathology 38, 247-259, 2018.

Imai H, Ohta K, Yoshida A, Suzuki S, Hashizume K, Usami S, Kikuchi T. \{mu\}-Crystallin, new candidate protein in endotoxin-induced uveitis. Invest Ophthalmol Vis Sci 51, 3554-3559, 2010.

Jansen J, Friesema EC, Milici C, Visser TJ. Thyroid hormone transporters in health and disease. Thyroid 15, 757-768, 2005.

Jhanwar SC, Chaganti RS, Croce CM. Germ-line chromosomal localization of human C-Erb-A oncogene. Somat Cell Mol Genet 11, 99-102, 1985.

Johnston-Wilson NL, Sims CD, Hofmann JP, Anderson L, Shore AD, Torrey EF, Yolken RH. Disease-specific alterations in frontal cortex brain proteins in schizophrenia, bipolar disorder, and major depressive disorder. The Stanley Neuropathology Consortium. Mol Psychiatry 5, 142-149, 2000.

Joshi SS, Sethi M, Striz M, Cole N, Denegre JM, Ryan J, Lhamon ME, Agarwal A, Murray S, Braun RE, Fardo DW, Kumar V, Donohue KD, Sunderam S, Chesler EJ, Svenson KL, O’Hara BF. Noninvasive sleep monitoring in large-scale screening of knock-out mice reveals novel sleep-related genes. bioRxiv, 517680, 2019.

Kalmar B, Blanco G, Greensmith L. Determination of Muscle Fiber Type in Rodents. Curr Protoc Mouse Biol 2, 231-243, 2012.

Kalyanaraman H, Schwappacher R, Joshua J, Zhuang S, Scott BT, Klos M, Casteel DE, Frangos JA, Dillmann W, Boss GR, Pilz RB. Nongenomic thyroid hormone signaling occurs through a plasma membrane-localized receptor. Sci Signal 7, ra48, 2014.

Kim RY, Gasser R, Wistow GJ. mu-crystallin is a mammalian homologue of Agrobacterium ornithine cyclodeaminase and is expressed in human retina. Proc Natl Acad Sci U S A 89, 9292-9296, 1992.

Kinney CJ, O’Neill A, Noland K, Huang W, Muriel J, Lukyanenko V, Kane MA, Ward CW, Collier AF, Roche JA, McLenithan JC, Reed PW, Bloch RJ. $\mu$-Crystallin in mouse skeletal muscle promotes a shift from glycolytic toward oxidative metabolism. Current Research in Physiology 4, 47-59, 2021.

Kobayashi M, Hashizume K, Suzuki S, Ichikawa K, Takeda T. A novel NADPH-dependent cytosolic 3,5,3'-triiodoL-thyronine-binding protein (CTBP; 5.1S) in rat liver: a comparison with 4.7S NADPH-dependent CTBP. Endocrinology 129, 1701-1708, 1991.

Kubota K, Uchimura H, Mitsuhashi T, Chiu SC, Kuzuya N, Nagataki S. Effects of intrathyroidal metabolism of thyroxine on thyroid hormone secretion: increased degradation of thyroxine in mouse thyroids stimulated chronically with thyrotrophin. Acta Endocrinol (Copenh) 105, 57-65, 1984.

Larsen PR, Silva JE, Kaplan MM. Relationships between circulating and intracellular thyroid hormones: physiological and clinical implications. Endocr Rev 2, 87-102, 1981.

Legradi G, Emerson CH, Ahima RS, Flier JS, Lechan RM. Leptin prevents fasting-induced suppression of prothyrotropin-releasing hormone messenger ribonucleic acid in neurons of the hypothalamic paraventricular nucleus. Endocrinology138, 2569-2576, 1997.

Lein ES, Hawrylycz MJ, Ao N, Ayres M, Bensinger A, Bernard A et al. Genome-wide atlas of gene expression in the adult mouse brain. Nature 445, 168-176, 2007.

Liu X, Wei S, Deng S, Li D, Liu K, Shan B, Shao Y, Wei W, Chen J, Zhang L. Genome-wide identification and comparison of mRNAs, lncRNAs and circRNAs in porcine intramuscular, subcutaneous, retroperitoneal and mesenteric adipose tissues. Anim Genet 50, 228-241, 2019.

Liu YY, Milanesi A, Brent GA. Thyroid Hormones. In: Hormonal Signaling in Biology and Medicine (Ed. G. Litwack), pp. 487-506, Elsevier, 2020.

Lusk G. Animal calorimetry: twenty-fourth paper. Analysis of the oxidation of mixtures of carbohydrate and fat J Biol Chem 59, 41-42, 1924.

Mansourian AR. A review on hyperthyroidism: thyrotoxicosis under surveillance. Pak J Biol Sci 13, 1066-1076, 2010.

Martins-de-Souza D, Gattaz WF, Schmitt A, Rewerts C, Maccarrone G, Dias-Neto E, Turck CW. Prefrontal cortex shotgun proteome analysis reveals altered calcium homeostasis and immune system imbalance in schizophrenia. Eur Arch Psychiatry Clin Neurosci 259, 151-163, 2009a. 
Martins-de-Souza D, Gattaz WF, Schmitt A, Maccarrone G, Hunyadi-Gulyás E, Eberlin MN, Souza GH, Marangoni S, Novello JC, Turck CW, Dias-Neto E. Proteomic analysis of dorsolateral prefrontal cortex indicates the involvement of cytoskeleton, oligodendrocyte, energy metabolism and new potential markers in schizophrenia. J Psychiatr Res 43, 978-986, 2009b.

Martins-de-Souza D, Maccarrone G, Wobrock T, Zerr I, Gormanns P, Reckow S, Falkai P, Schmitt A, Turck CW. Proteome analysis of the thalamus and cerebrospinal fluid reveals glycolysis dysfunction and potential biomarkers candidates for schizophrenia. J Psychiatr Res 44, 1176-1189, 2010.

Mendoza A, Hollenberg AN. New insights into thyroid hormone action. Pharmacol Ther 173, 135-145, 2017.

Mengeling BJ, Pan F, Privalsky ML. Novel mode of deoxyribonucleic acid recognition by thyroid hormone receptors: thyroid hormone receptor beta-isoforms can bind as trimers to natural response elements comprised of reiterated half-sites. Mol Endocrinol 19, 35-51, 2005.

Middleton FA, Mirnics K, Pierri JN, Lewis DA, Levitt P. Gene expression profiling reveals alterations of specific metabolic pathways in schizophrenia. J Neurosci 22, 2718-2729, 2002.

Miga KH, Eisenhart C, Kent WJ. Utilizing mapping targets of sequences underrepresented in the reference assembly to reduce false positive alignments. Nucleic Acids Res 43, e133, 2015.

Mihaly E, Fekete C, Tatro JB, Liposits Z, Stopa EG, Lechan RM. Hypophysiotropic thyrotropin-releasing hormonesynthesizing neurons in the human hypothalamus are innervated by neuropeptide $\mathrm{Y}$, agouti-related protein, and alpha-melanocyte-stimulating hormone. J Clin Endocrinol Metab 85, 2596-2603, 2000.

Miklos GL, Maleszka R. Microarray reality checks in the context of a complex disease. Nat Biotechnol 22, 615-621, 2004.

Mitchell AM, Tom M, Mortimer RH. Thyroid hormone export from cells: contribution of P-glycoprotein. J Endocrinol 185, 93-98, 2005.

Mori J, Suzuki S, Kobayashi M, Inagaki T, Komatsu A, Takeda T, Miyamoto T, Ichikawa K, Hashizume K. Nicotinamide adenine dinucleotide phosphate-dependent cytosolic $\mathrm{T}(3)$ binding protein as a regulator for $\mathrm{T}(3)$ mediated transactivation. Endocrinology 143, 1538-1544, 2002.

Morley JE. Extrahypothalamic thyrotropin releasing hormone (TRH) -- its distribution and its functions. Life Sci 25, 1539-1550, 1979.

Mukai M, Replogle K, Drnevich J, Wang G, Wacker D, Band M, Clayton DF, Wingfield JC. Seasonal differences of gene expression profiles in song sparrow (Melospiza melodia) hypothalamus in relation to territorial aggression. PLoS One 4, e8182, 2009.

O'Shea PJ, Williams GR. Insight into the physiological actions of thyroid hormone receptors from genetically modified mice. J Endocrinol 175, 553-570, 2002.

Ohkubo Y, Sekido T, Nishio SI, Sekido K, Kitahara J, Suzuki S, Komatsu M. Loss of $\mu$-crystallin causes PPAR $\gamma$ activation and obesity in high-fat diet-fed mice. Biochem Biophys Res Commun 508, 914-920, 2019.

Ojha A, Watve M. Blind fish: An eye opener. Evol Med Public Health 2018, 186-189, 2018.

Oshima A, Suzuki S, Takumi Y, Hashizume K, Abe S, Usami S. CRYM mutations cause deafness through thyroid hormone binding properties in the fibrocytes of the cochlea. J Med Genet 43, e25, 2006.

Pantos C, Mourouzis I. Thyroid hormone receptor $\alpha 1$ as a novel therapeutic target for tissue repair. Ann Transl Med 6, 254, 2018

Pensato V, Magri S, Bella ED, Tannorella P, Bersano E, Sorarù G, Gatti M, Ticozzi N, Taroni F, Lauria G, Mariotti C, Gellera C. Sorting Rare ALS Genetic Variants by Targeted Re-Sequencing Panel in Italian Patients: OPTN, VCP, and SQSTM1 Variants Account for 3\% of Rare Genetic Forms. J Clin Med 9, 412, 2020.

Phan L, Jin Y, Zhang H, Qiang W, Shekhtman E, Shao D, Revoe D, Villamarin R, Ivanchenko E, Kimura M, Wang ZY, Hao L, Sharopova N, Bihan M, Sturcke A, Lee M, Popova N, Wu W, Bastiani C, Ward M, Holmes JB, Lyoshin V, Kaur K, Moyer E, Feolo M, Kattman BL. “ALFA: Allele Frequency Aggregator.” National Center for Biotechnology Information, U.S. National Library of Medicine, 10 Mar. 2020, www.ncbi.nlm.nih.gov/ snp/docs/gsr/alfa/.

Pihlajamaki J, Boes T, Kim EY, Dearie F, Kim BW, Schroeder J, Mun E, Nasser I, Park PJ, Bianco AC, Goldfine AB, Patti ME. Thyroid hormone-related regulation of gene expression in human fatty liver. J Clin Endocrinol Metab 94, 3521-3529, 2009.

Pirahanchi Y, Tariq MA, Jialal I. Physiology, Thyroid. [Updated 2021 Feb 9]. In: StatPearls [Internet]. Treasure Island (FL): StatPearls Publishing; 2021. Available from: https:/www.ncbi.nlm.nih.gov/books/NBK519566/.

Raparti G, Jain S, Ramteke K, Murthy M, Ghanghas R, Ramanand S, Ramanand J. Selective thyroid hormone receptor modulators. Indian J Endocrinol Metab 17, 211-218, 2013. 
Reed PW, Corse AM, Porter NC, Flanigan KM, Bloch RJ. Abnormal expression of mu-crystallin in facioscapulohumeral muscular dystrophy. Exp Neurol 205, 583-586, 2007.

Rodriguez-Rodriguez A, Lazcano I, Sanchez-Jaramillo E, Uribe RM, Jaimes-Hoy L, Joseph-Bravo P, Charli JL. Tanycytes and the control of thyrotropin-releasing hormone flux into portal capillaries. Front Endocrinol (Lausanne) 10, 401, 2019.

Saetre P, Lindberg J, Leonard JA, Olsson K, Pettersson U, Ellegren H, Bergstrom TF, Vila C, Jazin E. From wild wolf to domestic dog: gene expression changes in the brain. Brain Res Mol Brain Res 126, 198-206, 2004.

Samocha KE, Robinson EB, Sanders SJ, Stevens C, Sabo A, McGrath LM, Kosmicki JA, Rehnstrom K, Mallick S, Kirby A, Wall DP, MacArthur DG, Gabriel SB, DePristo M, Purcell SM, Palotie A, Boerwinkle E, Buxbaum JD, Cook EH Jr, Gibbs RA, Schellenberg GD, Sutcliffe JS, Devlin B, Roeder K, Neale BM, Daly MJ. A framework for the interpretation of de novo mutation in human disease. Nat Genet 46, 944-950, 2014.

Sanchez E, Uribe RM, Corkidi G, Zoeller RT, Cisneros M, Zacarias M, Morales-Chapa C, Charli JL, Joseph-Bravo P. Differential responses of thyrotropin-releasing hormone (TRH) neurons to cold exposure or suckling indicate functional heterogeneity of the TRH system in the paraventricular nucleus of the rat hypothalamus. Neuroendocrinology 74, 407-422, 2001.

Sandler B, Webb P, Apriletti JW, Huber BR, Togashi M, Cunha Lima ST, Juric S, Nilsson S, Wagner R, Fletterick RJ, Baxter JD. Thyroxine-thyroid hormone receptor interactions. J Biol Chem 279, 55801-55808, 2004.

Sap J, Munoz A, Damm K, Goldberg Y, Ghysdael J, Leutz A, Beug H, Vennstrom B. The c-erb-A protein is a highaffinity receptor for thyroid hormone. Nature 324, 635-640, 1986.

Sapp PC, Hosler BA, McKenna-Yasek D, Chin W, Gann A, Genise H, Gorenstein J, Huang M, Sailer W, Scheffler M, Valesky M, Haines JL, Pericak-Vance M, Siddique T, Horvitz HR, Brown RH Jr. Identification of two novel loci for dominantly inherited familial amyotrophic lateral sclerosis. Am J Hum Genet 73, 397-403, 2003.

Schaefer JS, Klein JR. Immunological regulation of metabolism--a novel quintessential role for the immune system in health and disease. FASEB J 25, 29-34, 2011.

Schiaffino S, Reggiani C. Fiber types in mammalian skeletal muscles. Physiol Rev 91, 1447-1531, 2011.

Schimmel M, Utiger RD. Thyroidal and peripheral production of thyroid hormones. Review of recent findings and their clinical implications. Ann Intern Med 87, 760-768, 1977.

Seko D, Ogawa S, Li TS, Taimura A, Ono Y. $\mu$-Crystallin controls muscle function through thyroid hormone action. FASEB J 30, 1733-1740, 2016.

Senese R, Cioffi F, de Lange P, Goglia F, Lanni A. Thyroid: biological actions of 'nonclassical' thyroid hormones. J Endocrinol 221, R1-R12, 2014.

Serrano M, Moreno M, Ortega FJ, Xifra G, Ricart W, Moreno-Navarrete JM, Fernandez-Real JM. Adipose tissue $\mu$-crystallin is a thyroid hormone-binding protein associated with systemic insulin sensitivity. J Clin Endocrinol Metab 99, E2259-E2268, 2014.

Silva JE. Thyroid hormone and the energetic cost of keeping body temperature. Biosci Rep 25, 129-148, 2005.

Sivagnanasundaram S, Crossett B, Dedova I, Cordwell S, Matsumoto I. Abnormal pathways in the genu of the corpus callosum in schizophrenia pathogenesis: a proteome study. Proteomics Clin Appl 1, 1291-1305, 2007.

Smith CM, Hayamizu TF, Finger JH, Bello SM, McCright IJ, Xu J, Baldarelli RM, Beal JS, Campbell J, Corbani LE, Frost PJ, Lewis JR, Giannatto SC, Miers D, Shaw DR, Kadin JA, Richardson JE, Smith CL, Ringwald M. The mouse Gene Expression Database (GXD): 2019 update. Nucleic Acids Res 47, D774-D779, 2019.

Snyder PJ, Utiger RD. Response to thyrotropin releasing hormone (TRH) in normal man. J Clin Endocrinol Metab 34, 380-385, 1972.

Sotelo-Rivera I, Cote-Velez A, Uribe RM, Charli JL, Joseph-Bravo P. Glucocorticoids curtail stimuli-induced CREB phosphorylation in TRH neurons through interaction of the glucocorticoid receptor with the catalytic subunit of protein kinase A. Endocrine 55, 861-871, 2017.

Sterling K, Campbell GA, Brenner MA. Purification of the mitochondrial triiodothyronine (T3) receptor from rat liver. Acta Endocrinol (Copenh) 105, 391-397, 1984.

Suzuki S, Suzuki N, Mori J, Oshima A, Usami S, Hashizume K. micro-Crystallin as an intracellular 3,5,3'-triiodothyronine holder in vivo. Mol Endocrinol 21, 885-894, 2007.

Tagami T, Yamamoto H, Moriyama K, Sawai K, Usui T, Shimatsu A, Naruse M. Identification of a novel human thyroid hormone receptor beta isoform as a transcriptional modulator. Biochem Biophys Res Commun 396, 983-988, 2010.

Tata JR. A cellular thyroxine-binding protein fraction. Biochim Biophys Acta 28, 91-94, 1958.

Tawil R, van der Maarel SM, Tapscott SJ. Facioscapulohumeral dystrophy: the path to consensus on pathophysiology. Skelet Muscle 4, 12, 2014. 
Tennessen JA, Bigham AW, O’Connor TD, Fu W, Kenny EE, Gravel S, McGee S, Do R, Liu X, Jun G, Kang HM, Jordan D, Leal SM, Gabriel S, Rieder MJ, Abecasis G, Altshuler D, Nickerson DA, Boerwinkle E, Sunyaev S, Bustamante CD, Bamshad MJ, Akey JM; Broad GO; Seattle GO; NHLBI Exome Sequencing Project. Evolution and functional impact of rare coding variation from deep sequencing of human exomes. Science 337, 64-69, 2012.

Thul PJ, Akesson L, Wiking M, Mahdessian D, Geladaki A, Ait Blal H, Alm T, Asplund A, Bjork L, Breckels LM, Backstrom A, Danielsson F, Fagerberg L, Fall J, Gatto L, Gnann C, Hober S, Hjelmare M, Johansson F, Lee S, Lindskog C, Mulder J, Mulvey CM, Nilsson P, Oksvold P, Rockberg J, Schutten R, Schwenk JM, Sivertsson A, Sjostedt E, Skogs M, Stadler C, Sullivan DP, Tegel H, Winsnes C, Zhang C, Zwahlen M, Mardinoglu A, Ponten F, von Feilitzen K, Lilley KS, Uhlen M, Lundberg E. A subcellular map of the human proteome. Science 356, eaal3321, 2017.

Uhlen M, Fagerberg L, Hallstrom BM, Lindskog C, Oksvold P, Mardinoglu A, Sivertsson A, Kampf C, Sjostedt E, Asplund A, Olsson I, Edlund K, Lundberg E, Navani S, Szigyarto CA, Odeberg J, Djureinovic D, Takanen JO, Hober S, Alm T, Edqvist PH, Berling H, Tegel H, Mulder J, Rockberg J, Nilsson P, Schwenk JM, Hamsten M, von Feilitzen K, Forsberg M, Persson L, Johansson F, Zwahlen M, von Heijne G, Nielsen J, Ponten F. Proteomics. Tissue-based map of the human proteome. Science 347, 1260419, 2015.

Vanderplanck C, Ansseau E, Charron S, Stricwant N, Tassin A, Laoudj-Chenivesse D, Wilton SD, Coppee F, Belayew A. The FSHD atrophic myotube phenotype is caused by DUX4 expression. PLoS One 6, e26820, 2011.

Velasco LF, Togashi M, Walfish PG, Pessanha RP, Moura FN, Barra GB, Nguyen P, Rebong R, Yuan C, Simeoni LA, Ribeiro RC, Baxter JD, Webb P, Neves FA. Thyroid hormone response element organization dictates the composition of active receptor. J Biol Chem 282, 12458-12466, 2007.

Visser WE, Wong WS, van Mullem AA, Friesema EC, Geyer J, Visser TJ. Study of the transport of thyroid hormone by transporters of the SLC10 family. Mol Cell Endocrinol 315, 138-145, 2010.

Visser WE, Friesema EC, Visser TJ. Minireview: thyroid hormone transporters: the knowns and the unknowns. Mol Endocrinol 25, 1-14, 2011

Walker DM, Zhao X, Ramakrishnan A, Cates HM, Cunningham AM, Pena CJ, Bagot RC, Issler O, Van der Zee Y, Lipschultz AP, Godino A, Browne CJ, Hodes GE, Parise EM, Torres-Berrio A, Kennedy PJ, Shen L, Zhang B, Nestler EJ. Adolescent social isolation reprograms the medial amygdala: transcriptome and sex differences in reward. bioRxiv, 955187, 2020.

Wang M, Li Q, Deng A, Zhu X, Yang J. Identification of a novel mutation in CRYM in a Chinese family with hearing loss using whole-exome sequencing. Exp Ther Med 20, 1447-1454, 2020.

Watanabe Y, Weiss RE. Thyroid hormone action. In: Encyclopedia of Endocrine Diseases, pp. 452-462, Elsevier, 2018.

Weinberger C, Thompson CC, Ong ES, Lebo R, Gruol DJ, Evans RM. The c-erb-A gene encodes a thyroid hormone receptor. Nature 324, 641-646, 1986.

Williams GR. Cloning and characterization of two novel thyroid hormone receptor beta isoforms. Mol Cell Biol 20, 8329-8342, 2000.

Williams GR, Bassett JH. Deiodinases: the balance of thyroid hormone: local control of thyroid hormone action: role of type 2 deiodinase. J Endocrinol 209, 261-272, 2011.

Wistow G, Kim H. Lens protein expression in mammals: taxon-specificity and the recruitment of crystallins. J Mol Evol 32, 262-269, 1991.

Yarbrough GG. On the neuropharmacology of thyrotropin releasing hormone (TRH). Prog Neurobiol 12, 291-312, 1979.

Zimmermann RC, Krahn LE, Klee GG, Ditkoff EC, Ory SJ, Sauer MV. Prolonged inhibition of presynaptic catecholamine synthesis with alpha-methyl-para-tyrosine attenuates the circadian rhythm of human TSH secretion. J Soc Gynecol Investig 8, 174-178, 2001. 